\title{
Al-Hikmah

\section{Halal Life Style sebagai Dakwah Determinasi Diri dan Sosial Masyarakat Indonesia}

\author{
Bahatma Baca \\ Universitas Islam Negeri Syarif Hidayatullah Jakarta \\ bahatmabaca@gmail.com
}

\begin{abstract}
Many people are starting to show their interest in the concept and understanding of the Halal lifestyle in their lives. This is because people tend to believe that Halal things are good for one's health and well-being. Halal things bring comfort and security to life. Therefore, the current study discusses how the Halal lifestyle can become self-determination and social Da'wah amongst Indonesian people as well as how the current form of Halal lifestyle is applied to their everyday life. The current study employed a descriptive method. The data obtained in this study are primary data from websites, books and journal articles. Literature study was mainly employed in the current study. Regarding the implementation of the Halal lifestyle, it affects people as consumers to be increasingly critical in making purchases on daily needs products, whether the consumables or services. Such gesture has made Halal industries proven to be able to compete with other industries of the same kind. Cosmetics with Halal label partially have positive and significant effects on consumers' decisions to buy Halal cosmetics. Halal tourist attractions are also deemed safer and more comfortable for their availability of prayer rooms and Halal culinary. Sharia hotels are also considered safer and more comfortable as a place to stay by eliminating liquor, discotheques and prohibiting unmarried visitors of different gender from booking or staying in the same room.
\end{abstract}

Keywords: Halal lifestyle, Dakwah, Determination.

\begin{abstract}
Abstrak
Banyak orang mulai menunjukkan ketertarikannya pada konsep serta pemahaman tentang gaya hidup halal dalam kesehariannya. Masyarakat percaya bahwa hal yang halal adalah hal yang baik untuk kesehatan dan keberlangsungan hidup. Hal yang halal mendatangkan kenyamanan dan keamanan bagi kehidupan. Penelitian ini membahas bagaimana halal life style dapat menjadi determinasi diri dan sosial masyarakat Indonesia. Bagaimana bentuk halal life style saat ini diaplikasikan pada kehidupan sehari-hari. penelitian ini menggunakan metode deskriptif. Data yang didapatkan pada penelitian ini data primer. bertujuan membahas metode penelitian kualitatif studi pustaka dan studi lapangan, dengan Kesimpulan penelitian ini ialah pengguna metode penelitian jenis kualitatif studi lapangan dipastikan lebih pada penelitian studi pustaka. Pembahasan pada penelitian ini tentang halal life style berpengaruh pada masyarakat yang menjadi konsumen semakin kritis dalam melakukan pembelian pada setiap produknya, baik mengkonsumsi produk makanan
\end{abstract}


maupun jasa. penelitian foodcourt halal Addict terbukti dapat bersaing dengan pengusaha-pengusaha yang lain. Kosmetik dengan label halal secara parsial memiliki pengaruh positif dan signifikan dalam keputusan konsumen untuk membeli kosmetik halal. Destinasi pariwisata halal menjadi tempat aman dan nyaman, adanya mushola, dan kuliner halal. Hotel Syariah juga menjadi tempat penginapan yang aman dan nyaman. Tanpa adanya minuman keras dan diskotek bahkan pengunjung harus menunjukan kartu tanda penduduk dengan alamat yang sama jika yang hendak menginap laki-laki dan perempuan.

Kata Kunci: Halal lyfestyle, Dakwah, Determinasi.

\section{Pendahuluan}

Banyak orang mulai menunjukkan ketertarikannya pada konsep serta pemahaman tentang gaya hidup halal dalam kesehariannya. Makanan halal menjadi perhatian paling banyak saat ini, bukan hanya makanan kemasan, makanan di Restoran juga menjadi banyak sorotan ke halalannya. Bukan hanya makanan, fasilitas hotel, layanan perbankan, sosialisasi, travelling, perlengkapan mandi perlengkapan kesehatan, kosmetik dan sebagainya. halal menempati kepentingan dari produsen, pelanggan, pemangku kepentingan, serta pengusaha. Semua aspek kehidupan ini tidak dapat dipisahkan dalam aktivitas rutin seorang muslim. Istilah halal life style secara umum belum ditetapkan tetapi secara eksplisit, tetapi secara implisit sudah disebutkan dalam al-Qur'an dan hadis.

Ketika barang dan jasa berorientasi halal ditawarkan, pada akhirnya gaya hidup halal akan menjadi keistimewaan tersendiri bagi umat Islam. Penelitian menyajikan gambaran umum dari istilah gaya hidup halal dan bagaimana mengarahkan potensi gaya hidup halal dalam keseharian. Juga tantangan yang terjadi dan akan terjadi nantinya ketika gaya hidup halal diterapkan. Gaya hidup halal menjadi suatu hal yang membawa pada kenyamanan dan keamanan masyarakat sendiri.

Dilihat dari banyaknya masyarakat lebih memilih produk yang sudah tertera logo halal. Tanpa banyak mengetahui kandungan asli dari produk tersebut menandakan. Bahwa determinasi diri dan sosial masyarakat dapat dilihat dari gaya hidup halal yang menjadi jaminan. Bahwa apa yang dilakukan, dikonsumsi oleh masyarakat adalah hal yang baik atau halal.

Karena masyarakat percaya bahwa hal yang halal adalah hal yang baik. Untuk kesehatan dan keberlangsungan hidup.

Hal yang halal mendatangkan kenyamanan dan keamanan bagi kehidupan. Seperti dalam al-Qur'an surat al-Baqarah ayat 172 disebutkan.

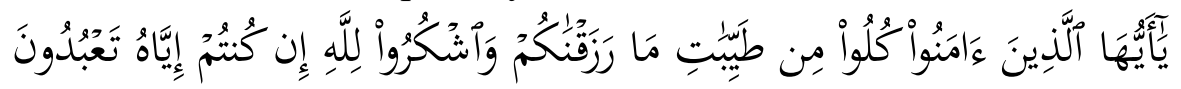

Hai orang-orang yang beriman, makanlah di antara rezeki yang baik-baik yang Kami berikan kepadamu dan bersyukurlah kepada Allah, jika benar-benar kepadaNya kamu menyembah.

Bagi al-Qurthubi, ayat tersebut merupakan penguat perintah mengonsumsi yang halal dan yang thayyib. Di sini Allah mengkhususkannya bagi orang Mukmin. 
Dan al-Qur'an surat al-Mu'minun ayat 51.

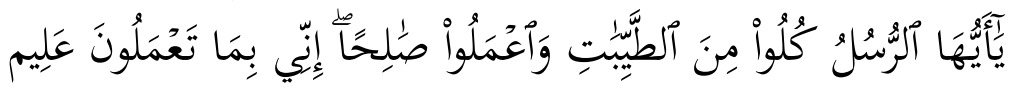

Hai rasul-rasul, makanlah dari makanan yang baik-baik, dan kerjakanlah amal yang saleh. Sesungguhnya Aku Maha Mengetahui apa yang kamu kerjakan.

Allah memerintahkan seluruh Rasul-Nya mengonsumsi makanan halal dan melakukan amal salih. Dengan ayat ini semakin jelas bahwa mengonsumsi yang halal bagian dari dari perintah syar'i dan amal salih, maka para Rasul pun telah melaksanakannya.

\section{Metode Penelitian}

Pendekatan penelitian ini menggunakan metode deskriptif. Data yang didapatkan pada penelitian ini data primer dari website, buku, dan jurnal. Sedangkan Perolehan data dengan cara observasi atau mencari referensi secara langsung dan juga data-data yang dapat menjadi keabsahan data penelitian. Jenis penelitian adalah deskriptif, dengan menggambarkan, menuangkan serta mempelajari masalah-masalah yang terjadi di masyarakat. Juga mengobservasi secara non partisipan bagaimana prilaku masyarakat serta pada satu situasi tertentu. Kegiatan tersebut adalah keberlangsung yang mempengaruhi suatu fenomena. Dengan metode deskriptif ini juga menyelidiki fenomena dari sudut pandang faktor-faktor tertentu. ${ }^{1}$

Teknik pengumpulan data pada penelitian ini dengan observasi dan dokumentasi. Dalam penelitian ini juga dapat dikatakan sebagai penelitian yang bertujuan membahas metode penelitian kualitatif studi pustaka dan studi lapangan, dengan Kesimpulan penelitian ini ialah pengguna metode penelitian jenis kualitatif studi lapangan dipastikan lebih pada penelitian studi pustaka.

Pada penelitian ini, peneliti akan meneliti bagaimana halal life style dapat menjadi determinasi diri dan sosial masyarakat Indonesia. Bagaimana bentuk halal life style saat ini diaplikasikan pada kehidupan sehari-hari.

\section{Definisi Istilah}

1. Halal life style

Halal lifestyle dapat dikatakan sebagai bagaimana cara hidup yang benar dan baik. Mengikuti prinsip Syariah dan koridor ketentuan tentang halal dan haram. Sedangkan kata Halal berasal dari bahasa Arab yang mempunyai makna pada tafsir al-Quran yaitu segala sesuatu yang telah diizinkan oleh syariah. Syariah menjelaskan tatanan hidup, dan segala sesuatu larangan yang jelas untuk makan dan minum, bermuamalah dan serta mengatur tentang sikap manusia dalam kehidupan pribadi dan sosialnya. ${ }^{2}$

2. Dakwah

\footnotetext{
${ }^{1}$ Tarjo, Metode Penelitian Sistem 3x Baca (Deepublish, 2019), 29.

${ }^{2}$ Hendri Hermawan Adinugraha dan Mila Sartika, "HALAL LIFESTYLE DI INDONESIA," 1, 6 (2019): 62, https://doi.org/10.21274/an.2019.6.1.57-81.
} 
Dakwah sesuai apa yang disampaikan oleh Quraish Shihab ajakan atau seruan ke arah keinsafan, bentuk ikhtiar makhluk atau usaha memperbaiki diri atau mengubah keadaan kepada situasi yang lebih baik kepada hal yang sempurna. Baik terhadap pribadi diri sendiri atau masyarakat pada umumnya. Tetapi dakwah bukan hanya usaha bagaimana meningkatkan pemahaman dalam tingkah laku sehari-hari saja. Tetapi merubah pandangan hidup menuju ke arah yang lebih luas, terlebih lagi pada masa sekarang ini, dakwah lebih berperanan menuju kepada pelaksanaan ajaran Islam secara lebih menyeluruh dalam berbagai aspek kehidupan. ${ }^{3}$

3. Determinasi

Menurut KBBI determinasi adalah hal yang menentukan (menetapkan, memastikan) arti sebuah kata dilihat dari hubungannya dalam kalimat secara keseluruhan ketetapan hati (dalam mencapai maksud atau tujuan)

\section{Pembahasan}

\section{Halal dalam al-Qur'an dan hadis}

Kata halal di dalam al-Qur'an terdapat pada beberapa tempat: "Wahai Manusia! makanlah dari (makanan) yang halal dan baik yang terdapat di bumi, dan janganlah kamu mengikuti langkah-langkah setan. Sungguh setan itu musuh yang nyata bagimu." (QS: al-Baqarah: 168). "Dihalalkan bagi kamu pada malam hari bulan puasa bercampur dengan istrimu. Mereka adalah pakaian bagimu, dan kamu adalah pakaian bagi mereka (QS: al-Baqarah: 187). ${ }^{4}$ "Dan sebagai seorang yang membenarkan Taurat yang datang sebelumku, dan agar aku menghalalkan bagi kamu sebagian dari yang telah diharamkan untukmu." (QS: Āli 'Imrān: 50). ${ }^{5}$ "Semua makanan adalah halal bagi Bani Israil, kecuali makanan yang diharamkan oleh Israil (Ya'qub) untuk dirinya sendiri sebelum Taurat diturunkan." (QS: Âli 'Imrān: 93). ${ }^{6}$

Secara etimologis, kata "halal" berasal dari kata kerja halla-yahullu, Artinya melepaskan atau membubarkan, halla-yahillu, artinya turun, lewat jatuh. Dalam alQur'an surat al-Mā'idah ayat 88 disebutkan: kulū mimmā rozaqakumullāh ḥalālan tayyiban, kata "halal" memiliki arti dapat dikonsumsi. Begitu pula di dalam alQur'an al-Mā'idah ayat 2: idzā halaltum fa-iștādū yang mempunyai arti setelah selesai dari ihram sesudah mengerjakan haji ataupun umrah, maka berburulah (mencari makanan yang halal). Terakhir, dalam surah al-Balad ayat 2: wa anta hillun bi-hādza al-balad yang mempunyai arti tinggal bebas, tanpa adanya larangan.

Dalam Kamus Besar Bahasa Indonesia halal diartikan dengan diizinkan (tidak dilarang oleh syarak). Dapat juga diartikan dengan sah, sebagai contoh: anak

\footnotetext{
${ }^{3}$ Eri Satria dan Roslan Mohamed, “ANALISIS TERHADAP PERANAN NASYID DALAM DAKWAH,” Jurnal Ilmiah Islam Futura 16, no. 2 (18 Juli 2017): 229, https://doi.org/10.22373/jiif.v16i2.1329.

${ }^{4}$ Yayasan Penyelenggara Penerjemah al-Quran, Al-Qur'an Terjemah al-Muhaimin (Depok: Al-Huda, 2002), 30.

${ }^{5}$ Ibid., 57.

${ }^{6}$ Ibid., 63.

4 | Bahatma Baca
} 
halal maksudnya anak yang sah. ${ }^{7}$

Secara luas, halal adalah segala sesuatu yang tidak secara mutlak dilarang oleh agama (syarī $a h)$. Dalam sebuah hadis riwayat at-Tirmidzī ${ }^{8}$, ibn Mājah ${ }^{9}$, dan Mālik, dengan lafal yang bervariasi, dari Salmān al-Fārisī dan 'Abdullāh bin 'Umar dinyatakan bahwa halal itu adalah semua yang dibolehkan oleh Allah dalam kitabnya (al-halāl mā ahalla Allāh fì kitābihi). Bahwa definisi 'boleh' itu segala perbuatan yang tidak ada sangsi pidana apabila dilakukan (al-jā'iz mā lā 'iqāba 'alā fi 'lihi).

Pembahasan halal merupakan pembahasan yang amat luas. Sebagai contoh, jika dilihat dari sudut makanan saja, makanan tersebut bisa dikatakan halal jika makanan dihasilkan dengan menggunakan bahan mentah, atau komponen dan aditif yang halal. Serta proses pembuatannya melalui panduan yang ditetapkan oleh syariat. Dengan kata lain, makanan halal harus ditinjau dari awal mula penyediaan, pemprosesan, penyimpanan, pembungkusan, pengendalian dan pengangkutan. Semuanya harus sesuai dengan syariat yang ada.

Maka dengan pengertian halal yang luas ini memberi gambaran tentang betapa pentingnya konsep halal ini diterapkan dalam kehidupan sehari-hari. Karena mematuhi segala hal juga melaksanakan hidup dengan standar halal yang ditetapkan oleh Allah masyarakat dan negara.

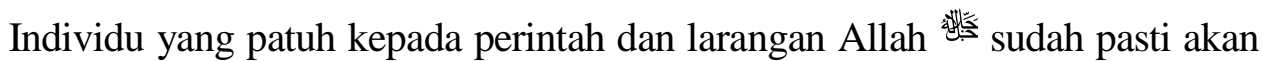
menjadi individu yang amanah kepada tugasnya. Mereka yang amanah sudah pasti menghasilkan kerja yang bermutu dan berkualitas. Masyarakat yang berkualitas sudah pasti menghasilkan kerja-kerja positif. Karena sesungguhnya Naluri Manusia selalu menginginkan hal yang berkualitas dalam hidupnya.

\section{Halal Life Style}

Pada dua dekade terakhir gaya hidup masyarakat di Indonesia mengacu pada nilai-nilai Islam terbukti dengan perkembangan busana hijab, penambahan hotel syariah, meningkatnya ibadah haji dan umrah, perkembangan penjualan kosmetik halal, serta wisata halal. ${ }^{10}$

Di era sekarang, berhijab tidak lagi dianggap terbelakang, justru berhijab atau berjilbab dapat menjadi begitu modern, trendy dan diminati. Fenomena revolusi hijabers tidak hanya dalam kehidupan nyata saja, bahkan semakin booming dengan hadirnya media sosial seperti Facebook, Twitter, Instagram, dan sebagainya. Para

7 Dendy Sugono dkk., Kamus Bahasa Indonesia (Jakarta: Pusat Bahasa Departemen Pendidikan Nasional, 2008), 518.

${ }^{8}$ Imam Tirmidhī, Sunan al-Tirmidhī (Stuttgart: Maknaz Islamy, 2010), 460.

${ }^{9}$ Ibn Mājah, Sunan ibn Mājah (Stuttgart: Maknaz Islamy, 2010), 491.

${ }^{10}$ Syafrida Hafni Sahir dan Eka Dewi Setia Tarigan, "Pengaruh Gaya Hidup, Label Halal dan Harga Terhadap Keputusan Pembelian Kosmetik Wardah pada Mahasiswa Program Studi Manajemen Fakultas Ekonomi Universitas Medan Area Medan," Jurnal Konsep Bisnis dan Manajemen 3, no. 1 (2016): 1. 
muda-mudi rela mengikuti trend para artis maupun selebran dengan model hijab terbaru. Trend para artis ini semakin banyak digandrungi muda-mudi walaupun mereka harus rela mengeluarkan biaya yang tidak sedikit. Produk fashion muslimah menjadi yang paling menarik diminati di negara muslim terutama di Indonesia. Berdasarkan laporan State of The Global Islamic Economy tahun 2013, Indonesia menempati peringkat ketiga teratas, yakni mencapai $\$ 18,8$ milyar. Terbukti dengan online hijab store (Vanilla Hijab dan Hijab Princess yang mengantongi omzet tiap bulan hingga 450-500 juta. ${ }^{11}$

Dengan adanya halal life style konsumen semakin kritis dalam melakukan pembelian pada setiap produknya, baik mengkonsumsi produk makanan maupun jasa. Melihat potensi yang sangat besar pada halal life style di Indonesia, pemerintah bersama DPR sepakat mengeluarkan undang-undang no. 33 tahun 2014 tentang jaminan produk halal. Dalam undang-undang tersebut pemerintah harus dapat menjamin kehalalan produk yang beredar di Indonesia. Maka dibentuklah Badan Penyelenggara Jaminan Produk Halal (BPJPH) dengan tugas dan fungsi untuk memastikan produk yang masuk dan beredar serta diperdagangkan di Indonesia adalah produk yang halal. Secara spesifik tugas BPJS adalah melakukan registrasi halal, mengeluarkan sertifikasi halal, sertifikasi halal, membina serta mengawasi kehalalan produk, bekerjasama dengan seluruh seluruh stakeholder yang terkait, dan menetapkan standar halal pada sebuah produk. ${ }^{12}$

Indikator tren bisnis halal terlihat pada lima bidang industri terus menunjukkan kemajuan. Antara lain jasa keuangan islami (Islamic finance), makanan halal, busana muslim, media dan rekreasi halal, serta farmasi dan kosmetik halal.

Sayangnya, Indonesia menempati urutan kesepuluh dari negara-negara pelaksana ekonomi Islam itu. Kesepuluh besar negara tersebut adalah Malaysia, Uni Emirat Arab, Bahrain, Oman, Arab Saudi, Qatar, Kuwait, Yordania, Pakistan dan Indonesia. Kondisi ini menandakan bahwa industri halal di Indonesia masih tertinggal dibandingkan dengan beberapa negara tetangga, bahkan dengan negaranegara non-muslim.

Padahal Indonesia memiliki potensi yang cukup besar mengingat penduduk negara yang mayoritas beragama Islam. Namun posisi tertinggi untuk negara produsen makanan halal dikuasai oleh Malaysia, Brasil, Uni Emirat Arab dan Amerika Serikat.

\section{Makanan Halal}

Dalam sebuah penelitian foodcourt halal oleh Dinda Imani dik. di Bali, Ubud Islamic Food Addict terbukti dapat bersaing dengan pengusaha-pengusaha yang lain. Ia menggunakan akad ijarah dengan pelaku UMKM, dan bekerja sama dengan

11 Umi Khusnul Khotimah, "Labelisasi Halal Di Tengah Budaya Konsumsif," Jurnal Sosiologi Agama 12, no. 2 (22 Desember 2018): 284-85, https://doi.org/10.14421/jsa.2018.122-06.

12 "Badan Penyelenggara Jaminan Produk Halal - BPJPH," diakses 17 September 2020, http://www.halal.go.id/. 
bank syariah dalam pembiayaan foodcourt. Banyak keuntungan yang didapatkan oleh pihak manajemen, diantaranya: Tidak kesulitan untuk mencari koki yang mampu membuat makanan halal khas Indonesia. Bagi konsumen tidak perlu lagi khawatir mencari tempat halal yang enak dan elegan ketika wisata ke Bali. Jadi dengan maraknya halal life style akan memberikan dampak positif bagi UMKM maupun pengusaha dalam mengembangkan bisnisnya. ${ }^{13}$

Maka masyarakat juga bisa membuat makanan halal yang mudah diterima oleh konsumen yang peduli tentang keamanan makanan dan gaya hidup sehat seperti saat ini karena konsumen Muslim semakin sadar akan keberadaan makanan halal dan kebutuhan akan hal itu. Kesadaran umat Islam bukan hanya terkait bahwa suatu produk makanan adalah halal, akan tetapi mereka juga memiliki kesadaran dan rasa keingintahuan yang mendalam terkait integritas status halal yang dihasilkan oleh sebuah produsen yang mencakup semua kegiatan yang terlibat di sepanjang rantai produksi dan pasokan sehingga berbagai produk yang mereka beli benar-benar halal. Proses menuju halal bisa saja dimulai dari persiapan awal sampai akhir, misalnya produk daging halal proses persiapannya bisa saja dimulai dari pemotongan, yang kemudian dilanjutkan saat pengepakan), selanjutnya proses pengiriman juga dilakukan secara baik. Karena kebutuhan akan layanan pengiriman halal (halal logistic) saat ini sudah semakin meningkat karena tuntutan segmen pasar internasional terhadap produk halal. Proses pengiriman suatu produk halal dilakukan secara halal atau distribusinya dilakukan menurut prinsip-prinsip syariah yang berlaku dalam Islam. maka pihak produsen baik produk maupun jasa selalu mengacu pada nilai-nilai syariah Islam dalam menghasilkan dan menjual produk dan jasa mereka kepada masyarakat Muslim.

Oleh karena itu, umat Islam dapat menerapkan keyakinannya untuk memperoleh berbagai produk dan jasa dalam dunia bisnis. Makanan halal dalam konsep industri atau industri makanan Islam makanan adalah industri yang Termasuk pengolahan hasil pertanian, penanaman dan perikanan menjadi pangan, serta produk setengah jadi yang tidak langsung menjadi pangan

Industri makanan saat ini telah menjadi salah satu industri dengan pertumbuhan tercepat saat ini.

\section{Kosmetik Halal}

Tidak bisa dipungkiri dengan jumlah masyarakat muslim terbesar di dunia, Indonesia memiliki potensi yang yang besar untuk mengembangkan produk halal. Sehingga dalam beberapa tahun belakangan banyak muncul wisata halal, bank

13 Dinda Imani Khamasasyiah, Iffah Karimah, dan Rico Novianto, "Ubud Islamic Food Addict Sebagai Bentuk Inovasi Ekspansi Umkm Syariah di Indonesia,” Islamic LAW Journal, 1, 1 (2018): 139, http://www.js.law.ui.ac.id/index.php/about/article/view/15/pdf. 
syariah, hotel syariah dan sebagainya. Salah satu contohnya adalah penjualan kosmetik yang berlabel halal. Dalam jurnal konsep bisnis dan manajemen Safrida dkk. menyimpulkan bahwa label halal secara parsial memiliki pengaruh positif dan signifikan dalam keputusan konsumen untuk membeli kosmetik Wardah. Begitu pula dengan gaya hidup halal secara simultan berpengaruh positif dan signifikan terhadap keputusan untuk membeli kosmetik Wardah. ${ }^{14}$

Peningkatan pendapatan penduduk Indonesia juga menyebabkan perubahan Gaya hidup konsumen terutama kelas menengah. Konsumen saat ini Tidak hanya memperhatikan kebutuhan dasar (sandang, pangan dan papan), tetapi Konsumen juga mulai mempertimbangkan untuk memenuhi kebutuhan sekunder dan tersier mereka. Kebutuhan konsumen sekunder adalah kecantikan dan fashion termasuk kosmetik termasuk dalam kategori permintaan ini. Kosmetik juga mengikuti perubahan gaya hidup sehat dan alami juga mendorong wanita umat muslim di Indonesia menggunakan kosmetik halal dan organik.

\section{Wisata Halal}

Fenomena wisata halal mulai merebak di Indonesia. Wisata halal merupakan perwujudan dari nuansa religius dalam kehidupan sosial budaya dan sosial ekonomi sesuai dengan prinsip-prinsip syariah. Mila Sartika dkk. dalam penelitiannya menyebutkan bahwa desa wisata halal seharusnya menjadi bukti fleksibilitas syariah Islam dalam gaya hidup masa kini yang mengandung nilai halal dan thayyib pada sektor pariwisata guna menunjang ekonomi daerah yang barokah. Wisata halal juga dapat memberdayakan masyarakat lokal untuk meningkatkan ekonomi mereka.

Di antara tujuan berwisata dalam al-Qur'an adalah:

1. Meningkatkan nilai spiritualitas yaitu dengan mengenalkan bahwa Allah 慧 pencipta alam semesta ini;

2. Meningkatkan ekonomi yaitu dengan memberdayakan masyarakat dan potensi daerah; serta

3. Memberikan wawasan keilmuan. ${ }^{15}$

Berdasarkan sumber keunikannya, desa wisata halal setidaknya memiliki empat keunikan:

1. Keunikan budaya lokal;

2. Keunikan sumber daya alam;

${ }^{14}$ Sahir dan Tarigan, "Pengaruh Gaya Hidup, Label Halal dan Harga Terhadap Keputusan Pembelian Kosmetik Wardah pada Mahasiswa Program Studi Manajemen Fakultas Ekonomi Universitas Medan Area Medan," 12.

${ }^{15}$ Hendri Hermawan Adinugraha, "Desa Wisata Halal: Konsep Dan Implementasinya Di Indonesia," HUMAN FALAH: Jurnal Ekonomi Dan Bisnis Islam 5 (29 Juni 2018): 45, http://jurnal.uinsu.ac.id/index.php/humanfalah/article/view/1336. 
3. Perpaduan keunikan sumber daya dan budaya;

4. Keunikan aktivitas ekonomi kreatif.

Jika sebuah daerah sudah memiliki 4 keunikan tersebut maka desa tersebut memiliki potensi untuk menjadi desa wisata halal.

Pada perkembangannya desa wisata halal setidaknya ada lima komponen yang harus terpenuhi:

1. Restoran halal;

2. Halal life style;

3. Penginapan syariah;

4. Wisata religi dan alam; dan

5. 'Urf halal. ${ }^{16}$

Wisata halal tidak hanya mencakup keberadaan tempat wisata ziarah saja, tetapi juga ketersediaan fasilitas pendukung, seperti rumah makan menyediakan makanan halal dan tempat shalat serta hotel berdasarkan permintaan konsumen.

\section{Hotel Syari'ah}

Dalam penelitian Abdul Waris pada Hotel Graha Agung Semarang disimpulkan bahwa penerapan prinsip-prinsip syariah secara signifikan dapat meningkatkan minat konsumen untuk menggunakan Hotel Syariah. Semakin tinggi penerapan konsep-konsep syariah pada hotel tersebut maka semakin tinggi pula minat konsumen untuk memakai jasa hotel tersebut. Variabel kualitas pelayanan dan penerapan prinsip syariah memiliki pengaruh yang signifikan pada minat konsumen dalam menggunakan jasa hotel syariah (Hotel Graha Agung Semarang). ${ }^{17}$

\section{Kesimpulan}

Kesimpulan penulis dari apa yang sudah dipaparkan sebelumnya, adalah sebagai berikut:

1. Secara etimologis, kata "halal" berasal dari kata kerja halla-yahullu, Artinya melepaskan atau membubarkan, halla-yahillu, artinya turun, lewat jatuh. Mayoritas kata halal dalam al-Qur'an berhubungan dengan makanan yang dibolehkan Allah 能. Dalam sebuah hadis riwayat at-Tirmidzì, ibn Mājah dan Mālik, dengan variasi lafal, dari Salmān al-Fārisī dan 'Abdullāh bin 'Umar dinyatakan bahwa halal itu adalah semua yang dibolehkan oleh Allah dalam kitabnya (al-halāl māa ahalla Allāh fì kitābihi). Bahwa definisi 'boleh' itu segala perbuatan yang tidak ada sangsi pidana apabila dilakukan (al-jā' $i z$ ma $l \bar{a}$

${ }^{16}$ Ibid., 39, 44.

17 Abdul Warits, "Pengaruh Kualitas Pelayanan Dan Penerapan Prinsip-Prinsip Syari'ah Terhadap Minat Konsumen Hotel Syari'ah (Studi Kasus Pada Hotel Graha Agung Semarang)" (Tesis, IAIN Walisongo, 2009), 57, http://eprints.walisongo.ac.id/3684/. 
'iqāba 'alā fi 'lihi).

2. Dalam sebuah penelitian foodcourt halal oleh Dinda Imani dik. di Bali, Ubud Islamic Food Addict terbukti dapat bersaing dengan pengusaha-pengusaha yang lain. Hal tersebut membuktikan bahwa potensi halal foodcourt dapat berkembang di masa yang akan datang.

3. Fashion dan kecantikan memiliki potensi yang tinggi pada halal life style. Sebagai contoh kosmetik Wardah. Dengan memiliki brand halal, semakin meningkatkan minat konsumen untuk membeli produk tersebut.

4. Penelitian Mila Sartika dik. Menyebutkan bahwa desa wisata halal memiliki potensi yang besar. Selain meningkatkan ekonomi penduduk lokal, wisata halal juga dapat meningkatkan nilai spiritualitas, yakni semakin mendekatkan diri kepada Allah 能.

5. Penelitian Abdul Waris menunjukkan semakin tinggi penerapan konsep Syariah, semakin tinggi minat konsumen untuk menggunakan jasa hotel tersebut. Hal tersebut mengindikasikan potensi halal life style khususnya hotel syariah, sangat tinggi di mata masyarakat.

\section{Daftar Pustaka}

Adinugraha, Hendri Hermawan. "Desa Wisata Halal: Konsep Dan Implementasinya Di Indonesia." HUMAN FALAH: Jurnal Ekonomi Dan Bisnis Islam 5 (29 Juni 2018). http://jurnal.uinsu.ac.id/index.php/ humanfalah/article/view/1336.

Adinugraha, Hendri Hermawan, dan Mila Sartika. "HALAL LIFESTYLE DI INDONESIA," 1, 6 (2019). https://doi.org/10.21274/an.2019.6.1.57-81.

Ahadiyanto, Nuzul. Hubungan Dimensi KepribadianThe Big Five Personality

Dengan Tingkat Kesejahteraan Psikologis Narapidana. Jurnal Al-Hikmah, 2020, 18.1: 117-130.

Alwi, Muhammad Muhib. Pemberdayaan Ekonomi Masyarakat Berbasis Masjid di

Tengah Pandemi Covid-19. Jurnal Al-Hikmah, 2020, 18.1: 99-116.

Al Ahsani, Nasirudin. "Moderasi Beragama: Meninjau Hadis-Hadis Hukuman Mati

Bagi Orang Murtad." Jurnal Al-Hikmah 18.2 (2020): 61-82. https://doi.org/10.35719/alhikmah.v18i2.33.

"Kepemimpinan Perempuan Pada Masyarakat dalam

Perspektif Sa '̄ìd Ramaḍān Al-Būṭ̄ (Telaah Hadis Misoginis)." Jurnal Al-

Hikmah 18.1 (2020): 57-74. https://doi.org/10.35719/alhikmah.v18i1.23.

Andriani, Nita. Strategi Komunikasi Bisnis Mini Market Islam Sebagai Pendidikan

Kemandirian Santri. Jurnal Al-Hikmah, 2020, 18.2: 47-60.

Dawud, Mochammad. Menerapkan Manajemen Strategi Penyiaran untuk Penyiaran

Dakwah. Jurnal Al-Hikmah, 2019, 17.1: 109-140. 
Halal Life Style Sebagai Dakwah Determinasi Diri Dan Sosial Masyarakat Indonesia

Dawud, Mochammad; Choliq, Abdul. Manajemen Strategi Ala NU Tv 9 Menghadapi Televisi Swasta Lokal di Surabaya. Jurnal Al-Hikmah, 2020, 18.1: 75-98.

Elanda, Yelly. Komodifikasi Agama pada Perumahan Syariah di Surabaya. Jurnal Al-Hikmah, 2019, 17.1: 41-62.

Fauzi, Ahmad. Problematika Dakwah di Tengah Pandemi Covid 19 Mewabah. Jurnal Al-Hikmah, 2020, 18.1: 27-36.

Fitriani, Aprilya; SAVIRA, Amelia. Strategi Pengembangan Potensi Wisata Desa Bone-Bone Kabupaten Enrekang Provinsi Sulawesi Selatan. Jurnal AlHikmah, 2020, 18.2: 21-38.

Hadi, H. Sofyan. Manajemen Strategi Dakwah di Era Kontemporer. Jurnal AlHikmah, 2019, 17.1: 79-90.

Jannah, Hasanatul. Pondok Pesantren Sebagai Pusat Otoritas Ulama Madura. Jurnal Al-Hikmah, 2019, 17.1: 91-108.

"Badan Penyelenggara Jaminan Produk Halal - BPJPH.” Diakses 17 September 2020. http://www.halal.go.id/.

Khamasasyiah, Dinda Imani, Iffah Karimah, dan Rico Novianto. "Ubud Islamic Food Addict Sebagai Bentuk Inovasi Ekspansi Umkm Syariah di Indonesia." Islamic LAW Journal, 1, 1 (2018). http://www.js.law.ui.ac.id/ index.php/about/article/view/15/pdf.

Khotimah, Umi Khusnul. "Labelisasi Halal Di Tengah Budaya Konsumsif." Jurnal Sosiologi Agama 12, no. 2 (22 Desember 2018): 283-96. https://doi.org/10.14421/jsa.2018.122-06.

Mājah, Ibn. Sunan ibn Mājah. Stuttgart: Maknaz Islamy, 2010.

Nafis, Abdul Wadud. Islam, Peradaban Masa Depan. Jurnal Al-Hikmah, 2020, 18.2: 1-20.

Putra, Ferdian Ardani; FAUZI, Ahmad. Komunikasi KPU Dalam Menekan Golput di Jember. Jurnal Al-Hikmah, 2020, 18.2: 95-108.

Quran, Yayasan Penyelenggara Penerjemah al-. Al-Qur'an Terjemah al-Muhaimin. Depok: Al-Huda, 2002.

Rohmah, Mudrika; MUSYARROFAH, Anjumil; SULISTIYOWATI, Anugrah. Secure Attachment (Kelekatan Aman) Anak Usia Remaja Dengan Orang Tua Di Tengah Pandemi Covid-19. Jurnal Al-Hikmah, 2020, 18.2: 83-94.

Saputra, Adi. Pembentukan Konsep Diri Remaja Melalui Penanaman Nilai-Nilai Keislaman. Jurnal Al-Hikmah, 2020, 18.2: 39-46.

Setiawan, Eko. Makna Nilai Filosofi Wayang Kulit Sebagai Media Dakwah. Jurnal Al-Hikmah, 2020, 18.1: 37-56.

Sahir, Syafrida Hafni, dan Eka Dewi Setia Tarigan. "Pengaruh Gaya Hidup, Label Halal dan Harga Terhadap Keputusan Pembelian Kosmetik Wardah pada Mahasiswa Program Studi Manajemen Fakultas Ekonomi Universitas 
Medan Area Medan.” Jurnal Konsep Bisnis dan Manajemen 3, no. 1 (2016): 15.

Satria, Eri, dan Roslan Mohamed. "ANALISIS TERHADAP PERANAN NASYID DALAM DAKWAH.” Jurnal Ilmiah Islam Futura 16, no. 2 (18 Juli 2017): 227-42. https://doi.org/10.22373/jiif.v16i2.1329.

Sugono, Dendy, Meity Taqdir Qodratillah, Cormentyna Sitanggang, dan Menuk Hardaniwati. Kamus Bahasa Indonesia. Jakarta: Pusat Bahasa Departemen Pendidikan Nasional, 2008.

Tarjo. Metode Penelitian Sistem 3x Baca. Deepublish, 2019.

Tirmidhī, Imam. Sunan al-Tirmidhī. Stuttgart: Maknaz Islamy, 2010.

Warits, Abdul. "Pengaruh Kualitas Pelayanan Dan Penerapan Prinsip-Prinsip Syari'ah Terhadap Minat Konsumen Hotel Syari'ah (Studi Kasus Pada Hotel Graha Agung Semarang)." Tesis, IAIN Walisongo, 2009. http://eprints.walisongo.ac.id/3684/.

Wazis, Kun. Perlawanan Ahli Hadis terhadap Gerakan Radikalisme Dalam Konstruksi Media Online. Jurnal Al-Hikmah, 2019, 17.1: 20-40. 